\title{
IMPLEMENTATION OF DATA MINING FOR DETERMINING MAJORS USING K-MEANS ALGORITHM IN STUDENTS OF SMA NEGERI 1 PANGKALAN KERINCI
}

\section{Yuda Irawan}

STMIK Hang Tuah Pekanbaru

Yudairawan89@gmail.com

\begin{abstract}
SMA Negeri 1 Pangkalan kerinci is one of the middle schools located at Jalan Lintas Timur Kerinci Pelalawan Indonesia which currently has 2 majors namely Science and IPS. This student majors can lead learners to focus more on developing their own abilities and interests. Selection of inappropriate majors can be very detrimental to students of their interests and careers in the future. With the majors are expected to maximize the potential, talent or individual talents, so as to maximize academic value. Based on the background, then by applying data mining techniques are expected to help students to determine the correct majors in accordance with the criteria set. Data mining techniques used in the determination of this department using K-Means Algorithm.
\end{abstract}

Keywords: Data Mining, K-Means Algorithm, Senior High School

\section{INTRODUCTION}

State High School (SMA) 1 Pangkalan Kerinci is a government agency whose basic purpose is to hone the students' abilities during the education process. The function of education is not only in the teaching and learning process, but also includes guidance, selection and placement of student majors in accordance with their individual capacities. Therefore, the school plays an important role in being able to develop the potential that is owned by students.

Each student has different abilities and academic qualifications, so the school is responsible for directing students in the selection of the right majors. However, there are problems faced, the school difficulties in grouping majors students who have different abilities and academic qualifications, because so far the selection of majors in SMA Negeri 1 Pangkalan Kerinci is done based on the wishes of each student. Data mining is a method for finding new information that is useful from a large amount of data collection and can help in making decisions. Data mining can be used for several things, namely estimation, prediction, classification, clustering and association methods. In this research, clustering method with the kmeans algorithm will be applied. Clustering method is a technique of grouping data by separating data into a number of groups according to certain characteristics desired where the identity of the group from each data is unknown. With this grouping it is expected to find out which group of data can be identified and then be given an identity according to the problem at hand.

\section{LITERATURE REVIEW}

In this case the researchers conducted data collection from previous studies, namely research related to data mining clustering methods as a useful reference material to support this research. Below there are several studies relating to the problem to be investigated, namely:

Nurhayati and Pratiwi (2015) With the title "The Application of K-Means Algorithm in Data Mining for Department Specialization for Class X Students (Case Study: SMA Negeri 29 Jakarta)". The purpose of this study is to determine the majors for students grouped into two clusters. And then Putra \& Wadisman (2018) in their research study about data mining using KMeans algorithm and Tanagra software to implemented in selection of potential customers in MC Laundry. And then Rahayu (2019) discuss about IQ Expert System In Grouping Mental Reterdation Children With K-Means Algorithm.

Sulistiyani, et. al., (2015) with the title "Determination System of State High School 1 Karangmojo". This study will analyze the application of the K-means and TOPSIS algorithms to classify and rank high school students (SMA) based on UN scores, report cards, and placement test scores. 
Purnamaningsih, et. al., (2014) with the title "Utilization of the K-Means Clustering Method in Determining High School Student Management". The results of this study were carried out individually clustering for Natural Sciences / Social Sciences and presented the comparison of the results of K-Means clustering criteria for academic values, IQ scores, student interest with clustering K-Means academic grades. Student data is grouped individually according to their respective majors. The Natural Sciences majors are grouped into two, they are accepted by Natural Sciences and rejected by Natural Sciences. IPS majors are grouped into two, they are IPS and rejected IPS. Then each cluster is classified based on which criteria are prioritized. The cluster with the largest value in the final centroid is the cluster that IPA / IPS receives, while the cluster with the smallest value in the final centroid is the cluster that is rejected by IPA / IPS. It is almost same like Yunefri, et al., (2019) using K-Means Clustering, from the software that was built to help instructors in the subject of data structure in the process of grouping tutoring students. Grouping methods can be implemented to build valid student guidance grouping software.

Josi Aranda \& Wirda Astari Galvani Natasya (2016) with the title "The Application of the K-Means Cluster Analysis Method in the Concentration Selection Decision Support System for Yogyakarta Amikom Stmik International Class Students". The results of this study are to produce a decision support system for choosing concentration for students. Through this decision support system, it is expected to help direct students in choosing concentrations that are in accordance with their interests and abilities. Determination of concentration is based on the number of credits that have been taken during lectures and the weighting of the related course values available in the curriculum offered.

Yuda Irawan (2019) with the research title: Application Of Data Mining For Evaluation Of Sales Data Using Clustering And Divisive Hirarki Algorithm Methods In Pekanbaru World Media Company. The main purpose of this research using clustering method is grouping a number of data / objects into a cluster (group) so that the cluster will contain the same data as each group. In this study, the Divisive Hierarchy Algorithm is used to form clusters. The pattern obtained is expected to provide knowledge for Media World Pekanbaru companies as a supporting tool for making policy.

Johan Oscar Ong (2013) with the title "Implementation of K-means Clustering Algorithm to Determine President University's Marketing Strategy". The problem of this research is that because president university students come from various regions and even countries, special marketing strategies are needed in conducting marketing to find prospective students so that promotions are carried out more effectively and efficiently. And the results of this study are strategies to promote cities in regions in Indonesia with majors that are in great demand and the level of academic ability of prospective students.

\section{Research Methods}

\subsection{CRISP-DM method}

\subsubsection{Business Understanding Phase}

Understanding of business is done by studying the research object, namely at SMA Negeri 1 Pangkalan Kerinci. In this phase, the determination of business goals is to group students based on the grades achieved by each student in class X (Ten) in semester II.

\subsubsection{Data Understanding Phase}

The data used for the K-Means method analysis process is value data. The grades taken as the basis for the clustering process are semester II grades in class X (ten). After the data is obtained, the next process is to understand the data.

\subsubsection{Data Processing Phase (Data Preperation Phase)}

Data preparation is done by selecting the attributes that will be used for the modeling process taken from student data. The attributes that have been selected will be saved back into a new dataset that is ready to be processed into the modeling process.

\subsubsection{Modeling Phase}

The modeling stage will use clustering method with algorithm-means. In applying the clustering method, it will be divided into 2 clusters which will cluster the second semester grades in class $\mathrm{X}$ (ten). The modeling tool used is Rapidminer. 


\subsubsection{The Evaluation Phase}

At the evaluation stage the model will be assessed whether the results obtained from the clustering process have met the objectives set in the business understanding stage. At the stage of business understanding the goal has been determined, namely to determine the majors of students through semester II grades.

\subsubsection{Deployment Phase}

It is the application phase of the clastering technique in accordance with the goals of the objectives to be achieved in the first phase, which is to group students based on the grades achieved by each student in class X (ten) in semester II. From these results can also be known which students are entitled to occupy majoring in Natural Sciences and Social Sciences.

\section{RESEARCH RESULTS AND DISCUSSION}

\subsection{Problem Analysis}

To identify problems that exist in SMK Negeri 1 Pangkalan Kerinci in processing student majors data, an analysis of performance, information, economy, security or security, efficiency and service will be carried out. This analysis is also called PIECES Analysis. Where this analysis is as follows:

Table 1. Table 1 Pieces Analysis

\begin{tabular}{|c|c|c|c|}
\hline No & $\begin{array}{l}\text { Pieces } \\
\text { Analysis }\end{array}$ & Old System Analysis & New System Analysis \\
\hline 1 & Performance & $\begin{array}{l}\text { Reporting services to those } \\
\text { who are responsible for SMK } \\
\text { Negeri } 1 \text { Pangkalan Kerinci } \\
\text { have not been maximized and } \\
\text { are not efficient. }\end{array}$ & $\begin{array}{l}\text { In the form of a supporting } \\
\text { software in processing data } \\
\text { so that later it can smooth its } \\
\text { performance. }\end{array}$ \\
\hline 2 & Information & $\begin{array}{l}\text { During this time the } \\
\text { information generated has not } \\
\text { been able to produce specific } \\
\text { and efficient information, so } \\
\text { the processing of student } \\
\text { majors data has not been } \\
\text { carried out properly. }\end{array}$ & $\begin{array}{l}\text { In this research the } \\
\text { supporting software that will } \\
\text { be used is Rapidminer } \\
\text { software, where the } \\
\text { information obtained is more } \\
\text { specific and efficient. }\end{array}$ \\
\hline 3 & Control & $\begin{array}{l}\text { There is no security system at } \\
\text { SMK Negeri } 1 \text { Pangkalan } \\
\text { Kerinci. }\end{array}$ & $\begin{array}{l}\text { Development of the system is } \\
\text { safer and there are no } \\
\text { disturbances so that later it } \\
\text { can smooth the performance } \\
\text { of the responsible } \\
\text { department. }\end{array}$ \\
\hline 4 & Efficiency & $\begin{array}{l}\text { In the process of determining } \\
\text { the direction of students who } \\
\text { are currently still determined } \\
\text { manually by their desires. This } \\
\text { is not optimal. }\end{array}$ & $\begin{array}{l}\text { More efficient because it can } \\
\text { help in majors. }\end{array}$ \\
\hline 5 & Service & $\begin{array}{l}\text { In the service of parties in } \\
\text { SMK } 1 \text { Pangkalan Kerinci } \\
\text { have not been able to } \\
\text { effectively control student } \\
\text { majors, so that there is a } \\
\text { specialization in majors. }\end{array}$ & $\begin{array}{l}\text { With the application of data } \\
\text { mining is expected to } \\
\text { effectively control student } \\
\text { direction. }\end{array}$ \\
\hline
\end{tabular}

\subsection{CRISP-DM}

This research was conducted using the CRISP-DM (Cross Industry Standard Process for Data Mining) method. In this method there are 6 stages used, namely: 


\subsubsection{Business Understanding Phase}

Vocational High School 4 Vocational School located on Jalan Hang Tuah V Pangkalan Kerinci, is a school whose basic purpose is to hone students' abilities during the education process.

a. Determine Business Objectives (Determine Business Objectives)

The business objective of doing this research is to determine the pattern of student majors so that they can be used as one of the basic decision makers for determining the direction of students for the future.

b. Assess the situation (Asses The Situation)

Understand student majors at SMK Negeri 1 Pangkalan Kerinci in business goals and then translate them into data mining purposes.

c. Determine the Initial Data Mining Strategy

The initial strategy in this research is to review and request student data in advance at SMA Negeri 1 Pangkalan Kerinci.

\subsubsection{Data Understanding Phase}

The student dataset obtained from SMA Negeri 1 Pangkalan Kerinci is in the form of excel documents totaling 141 items in 2018. Following are the stages in the data understanding phase.

a. Initial Data Collection

The data collected and used in this data mining process are student data at SMK Negeri 1 Pangkalan Kerinci in 2017. Where the data collected consists of student names, classes, Nisn, student grades namely mathematics, physics, chemistry, biology, geography, sociology, economics and history. (Appendix 1)

b. The collected data will later be processed in the data mining stage using clustering.

Previously, the data that was collected had to be selected before entering the clustering process. So that in the grouping later it will be known which parts should be grouped in student majors data.

c. Describe Data

The student dataset consists of the attributes of the student's name, mathematics, physics, chemistry, biology, geography, sociology, economics and history. The amount of data in the attribute is 141 items. (Appendix 1).

d. Data Quality Evaluation

The results of the evaluation of the quality of the data are finding many empty or null values called missing values on the attributes in the student dataset.

e. Attribute Selection

In this study, the attributes used are student names, mathematics, physics, chemistry, biology, geography, sociology, economics and history. Which has 141 items. (Appendix 2)

\subsubsection{Data Processing Phase (Data Preparation Phase)}

Data preparation includes all activities to build student datasets that will be applied into the modeling tool, from the initial raw data in the form of student datasets and subsequently will do the data mining process.

a. Data Selection

Where the raw data to be selected in this study uses the attributes of student names, mathematics, physics, chemistry, biology, geography, sociology, economics and history in student data at SMK Negeri 1 Pangkalan Kerinci. (Appendix 2)

b. Raw Data Processing (Preprosessing Data)

At this stage it is a stage to ensure that the selected student's data is suitable for processing. After checking the data one by one and there is no problematic data after cleaning, then the usage data is combined in one group. The data groups will be tested in the K-means Algorithm process to form 2 groups in use.

\subsubsection{Data Modeling Phase}

Modeling is a phase that directly involves data mining techniques by selecting data mining techniques and determining the algorithm to be used. Data mining modeling in this study uses Rapid Miner software version 7.0. In this application a clustering algorithm is 
available in the form of the K-Means algorithm. Where is the K-Means flowchart algorithm as follows:

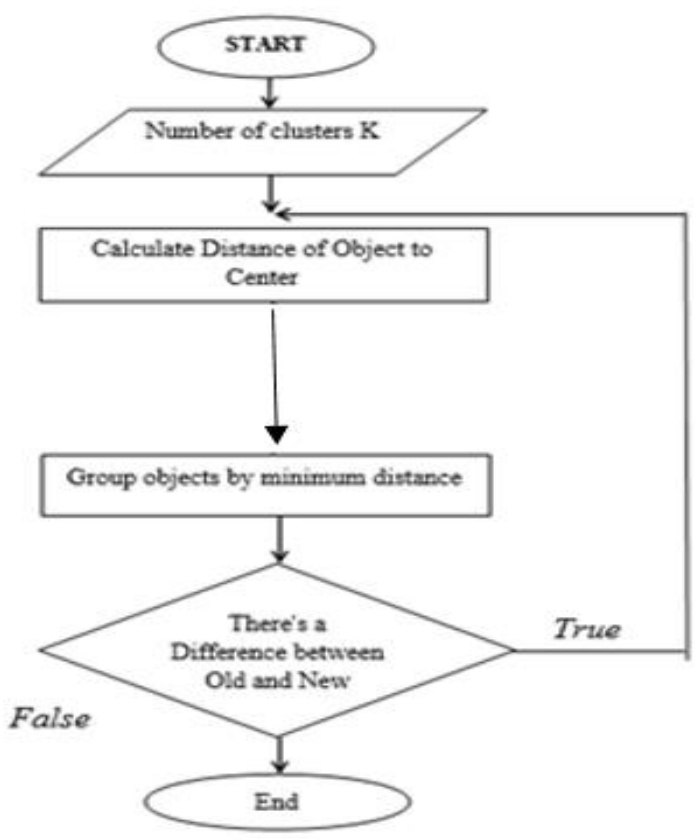

\subsubsection{Calculations with the K-Means Algorithm}

Figure 1. Flowchart Rapidminer.

a. Determination of Cluster Start Center

First of all the existing data will be grouped into 1 group. The initial center of a cluster or centroid is determined by the highest and lowest values. Here are the initial cluster centers for cluster 2 , cluster $1(89,88,86,87,88,89,90,90)$, cluster $2(69,68,68,70,70,70,69$, 73).

b. Calculate The Distance Of Each Data To Each Centroids

To calculate the distance of data to each centroids using the formula $1=$

$$
\sqrt{\left(C_{i j}-C_{k j}\right)^{2}+\left(C_{i j}-C_{k j}\right)^{2}+\cdots+\left(C_{i j}-C_{k j}\right)^{2}}
$$

Table 2. Student Data

\begin{tabular}{|c|c|c|c|c|c|c|c|c|c|}
\hline No & Student's Name & Math & physics & chemistry & biology & geography & Sosiology & Economy & History \\
\hline 1 & Ariaman & 79 & 69 & 65 & 70 & 70 & 73 & 70 & 70 \\
\hline 2 & $\begin{array}{l}\text { Corin Lamsihar } \\
\text { Sianturi }\end{array}$ & 79 & 67 & 70 & 67 & 88 & 75 & 82 & 80 \\
\hline 3 & Dandi Wahyudi & 70 & 75 & 75 & 75 & 83 & 80 & 79 & 75 \\
\hline 4 & $\begin{array}{l}\text { Daniel } \\
\text { Parlindungan } \mathrm{H}\end{array}$ & 72 & 70 & 70 & 75 & 80 & 81 & 80 & 80 \\
\hline 5 & Diki & 70 & 67 & 70 & 77 & 84 & 75 & 80 & 82 \\
\hline 6 & $\begin{array}{l}\text { Eka Rianti Br. } \\
\text { Malau }\end{array}$ & 85 & 84 & 80 & 87 & 89 & 88 & 88 & 90 \\
\hline 7 & Fajar Bakti & 80 & 75 & 70 & 73 & 85 & 80 & 79 & 80 \\
\hline 8 & Firman Syahroni & 79 & 79 & 80 & 70 & 80 & 81 & 88 & 80 \\
\hline 9 & Iklas Gabariela & 80 & 79 & 80 & 80 & 85 & 83 & 80 & 80 \\
\hline 10 & $\begin{array}{l}\text { Irsan Azi } \\
\text { Isnawan }\end{array}$ & 75 & 70 & 70 & 75 & 80 & 80 & 88 & 80 \\
\hline 11 & Irwan Juanda & 70 & 80 & 75 & 83 & 88 & 85 & 82 & 80 \\
\hline
\end{tabular}




\begin{tabular}{|c|c|c|c|c|c|c|c|c|c|}
\hline & Simare-Mare & & & & & & & & \\
\hline 12 & Irwanto & 71 & 70 & 75 & 70 & 79 & 80 & 88 & 80 \\
\hline 13 & Jadiaman & 78 & 77 & 77 & 75 & 80 & 81 & 80 & 80 \\
\hline 14 & $\begin{array}{l}\text { Jumaiza } \\
\text { Maherni }\end{array}$ & 77 & 75 & 73 & 80 & 79 & 80 & 80 & 80 \\
\hline 15 & Karina Natalia & 89 & 88 & 86 & 87 & 88 & 89 & 90 & 90 \\
\hline 16 & Kristina & 80 & 75 & 83 & 77 & 88 & 85 & 79 & 80 \\
\hline 17 & Lastri & 83 & 80 & 77 & 79 & 88 & 85 & 80 & 83 \\
\hline 18 & $\begin{array}{l}\text { Lismawati } \\
\text { Siagian }\end{array}$ & 79 & 75 & 75 & 80 & 80 & 83 & 80 & 80 \\
\hline 19 & $\begin{array}{l}\text { Lorida } \\
\text { Tampubolon }\end{array}$ & 79 & 76 & 70 & 77 & 73 & 77 & 79 & 80 \\
\hline 20 & $\begin{array}{l}\text { Madison Abibu } \\
\text { Sibarani }\end{array}$ & 70 & 75 & 70 & 75 & 80 & 79 & 75 & 80 \\
\hline 21 & Melisa & 70 & 70 & 77 & 85 & 88 & 85 & 80 & 88 \\
\hline 22 & Pianda Setiawan & 69 & 70 & 75 & 80 & 80 & 80 & 75 & 79 \\
\hline 23 & Pika Talia & 80 & 73 & 70 & 79 & 75 & 79 & 79 & 80 \\
\hline 24 & Rahul Arif F & 70 & 70 & 73 & 67 & 80 & 77 & 75 & 80 \\
\hline 25 & Ramadani & 70 & 70 & 75 & 77 & 88 & 89 & 85 & 90 \\
\hline 26 & $\begin{array}{l}\text { Rati Mantili } \\
\text { Situmorang }\end{array}$ & 71 & 70 & 77 & 75 & 81 & 81 & 80 & 79 \\
\hline 27 & Rindi Antika & 77 & 70 & 80 & 70 & 85 & 87 & 80 & 85 \\
\hline 28 & Suandrian & 77 & 74 & 79 & 80 & 78 & 80 & 80 & 83 \\
\hline 29 & $\begin{array}{l}\text { Sahman Tawar } \\
\text { Tanjung }\end{array}$ & 70 & 71 & 77 & 75 & 76 & 75 & 78 & 80 \\
\hline 30 & Septiani Pratiwi & 84 & 85 & 81 & 80 & 80 & 81 & 80 & 83 \\
\hline 31 & Siti Aminah Hsb & 75 & 79 & 77 & 80 & 80 & 83 & 79 & 81 \\
\hline 32 & Slamat Harianto & 70 & 75 & 70 & 71 & 77 & 75 & 70 & 75 \\
\hline 33 & Toni Kurniawan & 75 & 70 & 70 & 69 & 79 & 80 & 80 & 88 \\
\hline 34 & Tri Wulandari & 80 & 70 & 77 & 79 & 80 & 83 & 88 & 88 \\
\hline 35 & $\begin{array}{l}\text { Vera Yanti Br. } \\
\text { Boang Manalu }\end{array}$ & 85 & 80 & 80 & 84 & 88 & 85 & 87 & 90 \\
\hline 36 & Afriyana Mart & 84 & 85 & 80 & 80 & 88 & 80 & 85 & 90 \\
\hline 37 & $\begin{array}{l}\text { Agnes Heppi } \\
\text { Monika } \\
\text { Rumapea }\end{array}$ & 80 & 79 & 75 & 78 & 80 & 79 & 88 & 85 \\
\hline 38 & Agung Priyanto & 79 & 70 & 76 & 75 & 80 & 79 & 80 & 80 \\
\hline 39 & $\begin{array}{l}\text { Amelia Permata } \\
\text { Hati Marbun }\end{array}$ & 70 & 73 & 70 & 75 & 88 & 85 & 79 & 85 \\
\hline 40 & $\begin{array}{l}\text { Arnold Finesti } \\
\text { Tampubolon }\end{array}$ & 75 & 73 & 77 & 75 & 80 & 79 & 78 & 80 \\
\hline 41 & $\begin{array}{l}\text { Asniar } \\
\text { Nainggolan }\end{array}$ & 77 & 78 & 79 & 80 & 80 & 79 & 79 & 80 \\
\hline & . & . & . & . & . & $\dot{\square}$ & . & . & ${ }^{\circ}$ \\
\hline & . & . & . & . & . & . & . & . & . \\
\hline . & . & . & . & . & . & . & . & . & . \\
\hline 140 & $\begin{array}{l}\text { Selvia Dewi Br } \\
\text { Pasaribu }\end{array}$ & 80 & 79 & 75 & 79 & 83 & 81 & 79 & 85 \\
\hline 141 & Siska Hariani & 79 & 77 & 75 & 79 & 80 & 80 & 75 & 79 \\
\hline
\end{tabular}


Calculation of the distance in each data to get the closest centroid with the following formula:

Cluster 1

$$
\mathrm{D} 1=\sqrt{\begin{array}{c}
(79-89)^{2}+(69-88)^{2}+(65-86)^{2}+(70-87)^{2}+ \\
(70-88)^{2}+(73-89)^{2}+(70-90)^{2}+(70-90)^{2} \\
\vdots \\
=50,70502934
\end{array}}
$$

Cluster 2

$$
\mathrm{D} 1=\sqrt{\begin{array}{c}
\left.(79-69)^{2}+(69-68)^{2}+(65-68)^{2}+70-70\right)^{2}+ \\
\left((70-70)^{2}+(73-70)^{2}+(70-69)^{2}+(70-73)^{2}\right. \\
=11,35781669
\end{array}}
$$

Here are the results of the calculation of the distance of each data created in the form of a table.

\begin{tabular}{|c|c|c|c|}
\hline \multirow{2}{*}{ No } & \multicolumn{2}{|c|}{ Distance to } & \multirow{2}{*}{$\begin{array}{c}\text { Closest } \\
\text { Distance }\end{array}$} \\
\hline & $\mathrm{C} 1$ & $\mathrm{C} 2$ & \\
\hline 1 & 50,70502934 & 11,35781669 & 11,35781669 \\
\hline 2 & 39,45883931 & 26,0959767 & 26,0959767 \\
\hline 3 & 35,31288717 & 22,29349681 & 22,29349681 \\
\hline 4 & 36,61966685 & 20,80865205 & 20,80865205 \\
\hline 5 & 39,16631206 & 21,86321111 & 21,86321111 \\
\hline 6 & 8,602325267 & 47,74934555 & 8,602325267 \\
\hline 7 & 31,82766093 & 25,63201124 & 25,63201124 \\
\hline 8 & 27,16615541 & 31,55946768 & 27,16615541 \\
\hline 9 & 22,18107301 & 32,40370349 & 22,18107301 \\
\hline 10 & 34,19064199 & 26,05762844 & 26,05762844 \\
\hline 11 & 27,23967694 & 33,61547263 & 27,23967694 \\
\hline 12 & 36,3868108 & 25,45584412 & 25,45584412 \\
\hline 13 & 28,19574436 & 25,67099531 & 25,67099531 \\
\hline 14 & 29,88310559 & 24,2693222 & 24,2693222 \\
\hline 15 & 0 & 53,1789432 & 0 \\
\hline 16 & 24,41311123 & 33,7934905 & 24,41311123 \\
\hline 17 & 20,24845673 & 35,665109 & 20,24845673 \\
\hline 18 & 27,18455444 & 27,14774392 & 27,14774392 \\
\hline 19 & 34,49637662 & 20,59126028 & 20,59126028 \\
\hline 20 & 37,6696164 & 18,57417562 & 18,57417562 \\
\hline 21 & 29,83286778 & 34,72751071 & 29,83286778 \\
\hline 22 & 37,21558813 & 20,61552813 & 20,61552813 \\
\hline 23 & 33,40658618 & 22,04540769 & 22,04540769 \\
\hline 24 & 42,27292278 & 16,52271164 & 16,52271164 \\
\hline 25 & 30,5122926 & 36,51027253 & 30,5122926 \\
\hline 26 & 34,74190553 & 22,64950331 & 22,64950331 \\
\hline 27 & 30,5122926 & 31,48015248 & 30,5122926 \\
\hline
\end{tabular}

Table 3. Calculation of Cluster Center Distance 


\begin{tabular}{|c|c|c|c|}
\hline 28 & 27,71281292 & 26,57066051 & 26,57066051 \\
\hline 29 & 38,19685851 & 17,52141547 & 17,52141547 \\
\hline 30 & 19,62141687 & 35 & 19,62141687 \\
\hline 31 & 26,62705391 & 27,76688675 & 26,62705391 \\
\hline 32 & 44,5421149 & 11,5758369 & 11,5758369 \\
\hline 33 & 36,95943723 & 23,91652149 & 23,91652149 \\
\hline 34 & 25,65151068 & 33,7934905 & 25,65151068 \\
\hline 35 & 12,24744871 & 43,61192497 & 12,24744871 \\
\hline 36 & 15 & 41,55718951 & 15 \\
\hline 37 & 23,60084744 & 32,26453161 & 23,60084744 \\
\hline 38 & 32,12475681 & 23,32380758 & 23,32380758 \\
\hline 39 & 33,88214869 & 29,12043956 & 29,12043956 \\
\hline 40 & 32,46536616 & 21,86321111 & 21,86321111 \\
\hline 41 & 26,96293753 & 26,73948391 & 26,73948391 \\
\hline 42 & 31,4960315 & 28,31960452 & 28,31960452 \\
\hline 43 & 36,70149861 & 19,31320792 & 19,31320792 \\
\hline 44 & 39,66106403 & 18,02775638 & 18,02775638 \\
\hline 45 & 45,46427169 & 10,90871211 & 10,90871211 \\
\hline 46 & 47 & 13 & 13 \\
\hline 47 & 23,49468025 & 34,92849839 & 23,49468025 \\
\hline 48 & 29,22327839 & 34,40930107 & 29,22327839 \\
\hline 49 & 50,11985634 & 6,633249581 & 6,633249581 \\
\hline & & & \\
\hline & . & & \\
\hline & & & \\
\hline 140 & 24,12467616 & 30,09983383 & 24,12467616 \\
\hline 141 & 29.94995826 & 24,14539294 & 24,14539294 \\
\hline
\end{tabular}

c. Data Grouping

Distance calculation results at point 2 will be compared and selected the closest distance between the data with the center of the cluster, this distance will show that the data that has the closest distance is in one group with the closest cluster center, the grouping of data can be seen in table 4 . below this, a value of 1 means that the data is in groups.

Table 4. Grouping Data in Iteration 1 


\begin{tabular}{|r|r|r|}
\hline \multirow{2}{*}{ No } & \multicolumn{2}{|c|}{ Iteration 1 } \\
\cline { 2 - 3 } & C1 & \multicolumn{1}{|c|}{ C2 } \\
\hline 1 & & 1 \\
\hline 2 & & 1 \\
\hline 3 & & 1 \\
\hline 4 & & 1 \\
\hline 5 & & 1 \\
\hline 6 & 1 & \\
\hline 7 & & 1 \\
\hline 8 & 1 & \\
\hline 9 & 1 & \\
\hline 10 & & 1 \\
\hline 11 & 1 & \\
\hline 12 & & 1 \\
\hline 13 & & 1 \\
\hline 14 & & 1 \\
\hline 15 & 1 & \\
\hline 16 & 1 & \\
\hline 17 & 1 & \\
\hline 18 & & 1 \\
\hline 19 & & 1 \\
\hline 20 & & 1 \\
\hline 21 & 1 & \\
\hline 22 & & 1 \\
\hline 23 & & 1 \\
\hline 24 & & 1 \\
\hline & & \\
\hline
\end{tabular}

\begin{tabular}{|r|r|r|}
25 & 1 & \\
\hline 26 & & 1 \\
\hline 27 & 1 & \\
\hline 28 & & 1 \\
\hline 29 & & 1 \\
\hline 30 & 1 & \\
\hline 31 & 1 & \\
\hline 32 & & 1 \\
\hline 33 & & 1 \\
\hline 34 & 1 & \\
\hline 35 & 1 & \\
\hline 36 & 1 & \\
\hline 37 & 1 & \\
\hline 38 & & 1 \\
\hline 39 & & 1 \\
\hline 40 & & 1 \\
\hline 41 & & 1 \\
\hline 42 & & 1 \\
\hline 43 & & 1 \\
\hline 44 & & 1 \\
\hline 45 & & 1 \\
\hline. & & 1 \\
\hline. & & \\
\hline. & & \\
\hline 140 & 1 & \\
\hline 141 & & 1 \\
\hline
\end{tabular}

d. Determination of a new Cluster Center After obtaining members from each cluster then the new cluster center is calculated based on the data of each cluster member that has been obtained. The following results are explained in the table.

Table 5. Determination of New Cluster Centers

\begin{tabular}{|r|r|r|}
\hline \multirow{2}{*}{ No } & \multicolumn{2}{|c|}{ New Cluster } \\
\cline { 2 - 3 } & \multicolumn{1}{|c|}{ C1 } & \multicolumn{1}{c|}{ C2 } \\
\hline 1 & 79,59574468 & 73,79787234 \\
\hline 2 & 78,40425532 & 72,20212766 \\
\hline 3 & 77,53191489 & 71,61702128 \\
\hline 4 & 80,38297872 & 76,15957447 \\
\hline 5 & 83,80851064 & 79,9893617 \\
\hline 6 & 83,34042553 & 79,31914894 \\
\hline 7 & 82,61702128 & 78,55319149 \\
\hline 8 & 85,5106383 & 79,06976744 \\
\hline
\end{tabular}

The next iteration is done in the same way until there is no change in data in a cluster.

\subsubsection{Implementation by using RapidMiner}

Enter the 2 clusters specified in the clustering operator in the parameters. After that, click run to conduct the test, it will produce the test in 2 clusters. 


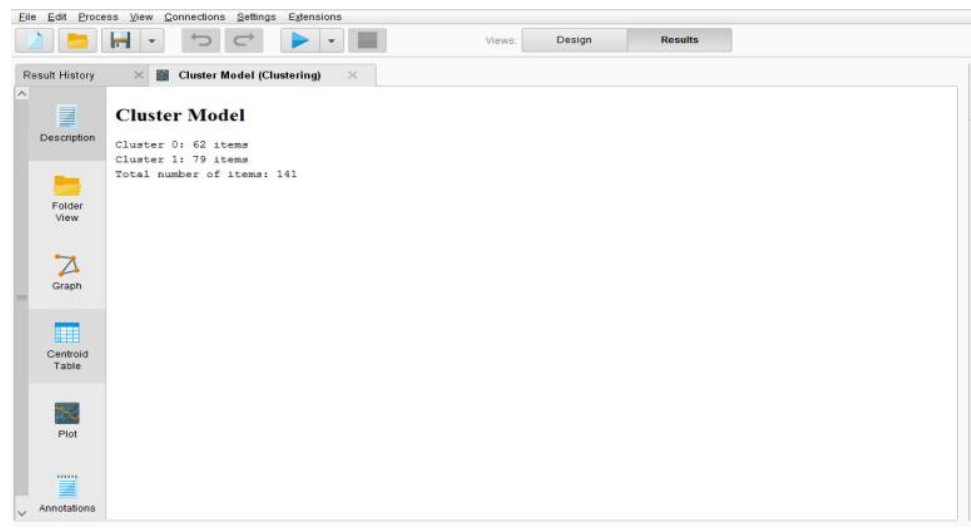

Figure 2. Display of test results

To see the Clustering results, click on the Description in the display as shown above. Description is to see the number of items contained in $\mathrm{CO}$ and $\mathrm{C} 1$.

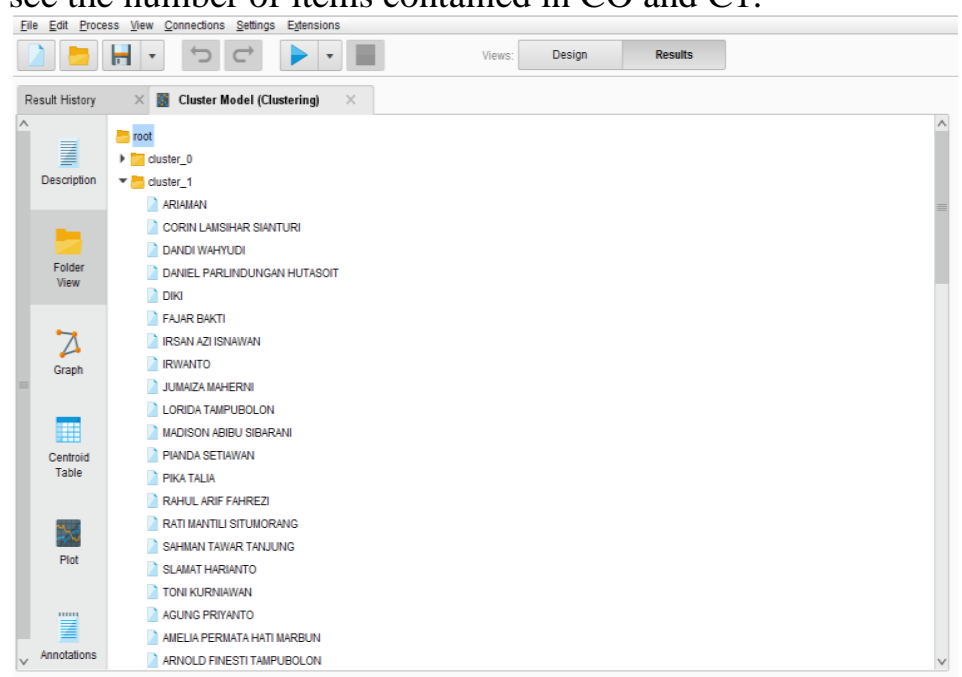

Figure 3. Cluster Display

The picture above is a display to see the data contained in each cluster. From Folder View we can see which data belongs to the data clusters group 0 and cluster 1 .

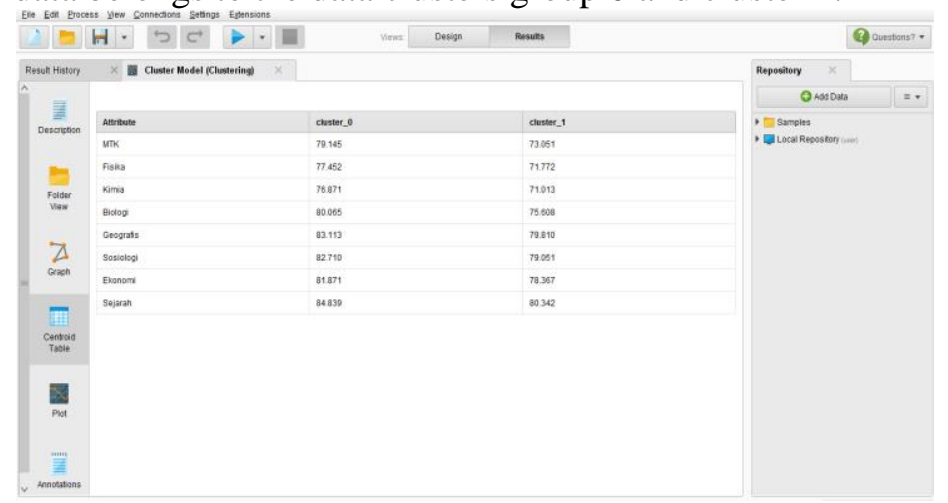

Figure 4. Display of Centroid Table

The picture above is the result of the centroid table. In the centroid table there are attributes. 


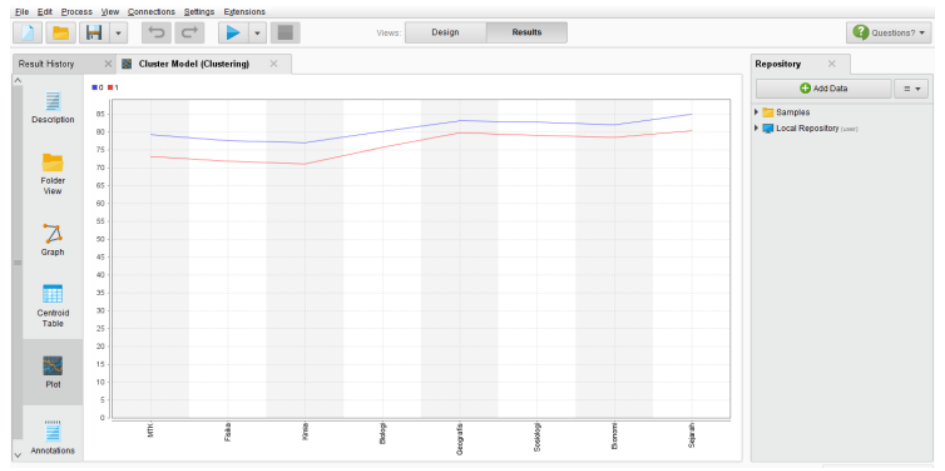

Figure 5. Plot Views

The picture above is the result of the plot display, which is a graph where the red line is $\mathrm{C} 1$ with the lowest value, which is around 71 , while the blue line is $\mathrm{C} 0$, with the highest value, 76 above and is included in the science department.

\subsubsection{Evaluation Phase}

Evaluation is an advanced phase of the purpose of data mining. Evaluation is carried out in depth with the aim that the results at the modeling stage are in line with the objectives to be achieved in the business understanding stage.

\subsubsection{Evaluation of Results}

This stage assesses the extent to which the results of data mining modeling meet the objectives of data mining that have been determined at the business understanding stage. Where in testing data that has been processed in Rapid Miner. testing the data in Rapid Miner used in this study is the index.

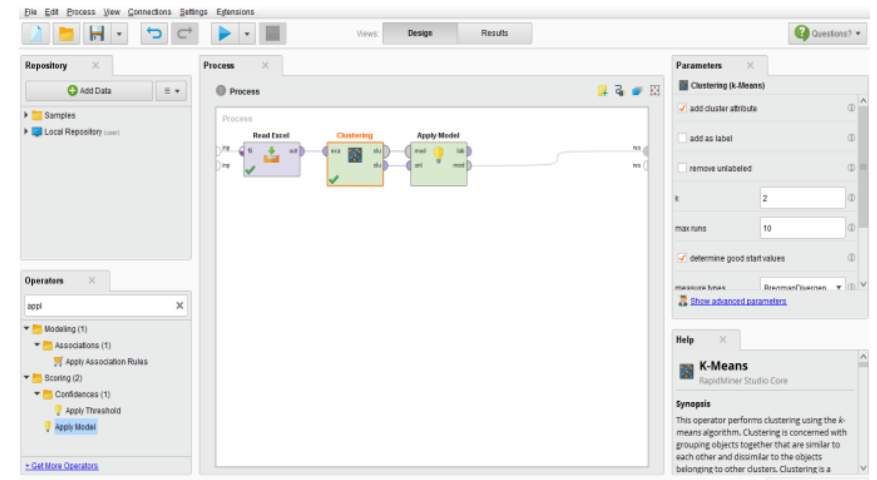

Figure 6. Display of apply models in the testing process

Take the apply model in the operators, then drag it into the process. Then connect the Kmeans with the apply model so that the testing process is successful, as shown above.

After the connection between K-means and apply models is carried out, the next step is to choose the cluster count performance in operators. Then drag the cluster performance count into the process.

The Apply model is used to read data to be clustered based on data that has been previously processed. Performance, this operator creates a performance vector that contains criteria for the number of clusters and the cluster number index of the cluster model.

After that click run, the results of the test data that will appear will appear. 


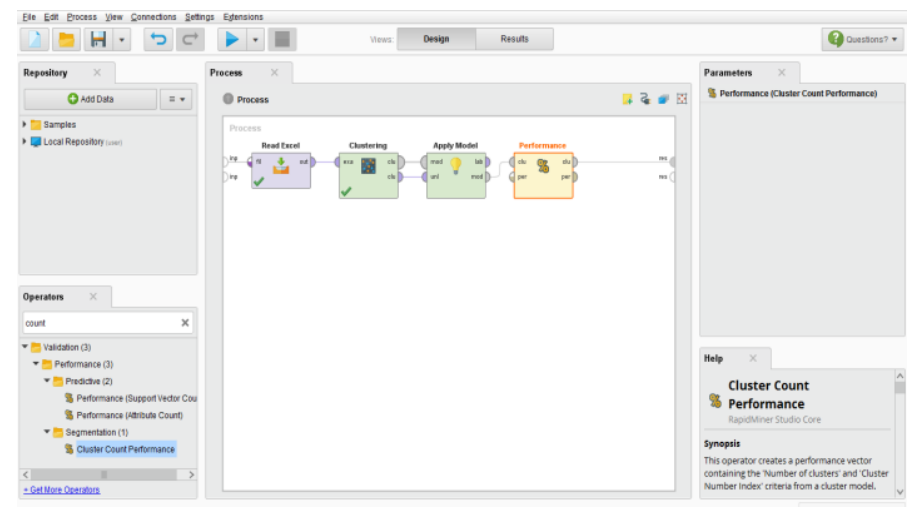

Figure 7. Display of Test Results

\subsubsection{Deployment Phase}

Deployment is the final stage in making reports on the results of data mining activities. The final report which contains the knowledge gained or pattern recognition in the data mining process.

\section{Cluster Analysis}

There are 8 attributes used in the clustering process namely Mathematics, physics, chemistry, biology, geography, sociology, economics and history. There are also 2 clusters used, cluster 0 taken from the highest value, cluster 1 taken from the lowest value. Here are the results of clustering:

1. Cluster 0, students with the highest category score, there are 62 students namely Eka rianti BR. Malau, Firman Syahroni, Iklas Gabariela, Karina Natalia, Kristina, Lastri, Irwan Juanda Simare-mare, Jadiaman, Lismawati Siagian, Melisa, Ramadhani, etc.

2. Cluster 1, students with low category grades, there are 79 namely Ariaman, Dandi wahyudi, Daniel parlindungan hutasoit, diki, Fajar devoted, Irsan azi isnaini, Pika talia, Amelia jewel of marbun heart, Rika rosa pertiwi, Riska dwiana untari, Devi anjani, etc.

\section{CONCLUSION \& SUGGESTION \\ Conclusion} including:

From the analysis and testing that has been done, the authors can draw conclusions

1. Can help in processing student data in high school, so that the school can be easier and faster in processing data.

2. With this system can help in determining school majors.

\section{Suggestions}

From the conclusions drawn, suggestions that writers can provide for improvements in data processing are:

1. In processing data majors students of Pangkalan Kerinci 1 High School for the future can be even better.

2. Because this system is new for the SMA Negeri 1 Pangkalan Kerinci course, it must be adjusted between the data and reports with the system used at this time.

\section{REFERENCES}

Aranda, J., \& Natasya, W. A. G. (2016). Penerapan Metode K-Means Cluster Analysis pada Sistem Pendukung Keputusan Pemilihan Konsentrasi Untuk Mahasiswa International Class STMIK Amikom Yogyakarta. Seminar Nasional Teknologi Informasi dan Multimedia 2016, di Yogyakarta, 6-7 Februari 2016.

Irawan, Y. (2019). Penerapan Data Mining Untuk Evaluasi Data Penjualan Menggunakan Metode Clustering Dan Algoritma Hirarki Divisive Di Perusahaan Media World Pekanbaru. Jurnal Teknologi Informasi Universitas Lambung Mangkurat (Jtiulm), 4(1), 13-20. 
Nurhayati \& Pratiwi, L. A. (2015). Penerapan Algoritma K-Means dalam Data Mining untuk Peminatan Jurusan Bagi Siswa Kelas X (Studi Kasus: SMA Negeri 29 Jakarta). Prosiding Seminar Ilmiah Nasional Teknologi Komputer (SENATKOM 2015) Oktober 2015, 1, 9-13.

Ong, J. O. (2013). Implementasi Algoritma K-Means Clustering Untuk Menentukan Strategi Marketing President University. Jurnal Ilmiah Teknik Industri, 12(1), 10-20.

Purnamaningsih, C., Saptono, R., \& Azis, A. (2014). Pemanfaatan Metode K-Means Clustering dalam Penentuan Penjurusan Siswa SMA. ITSMART: Jurnal Teknologi dan Informasi, $3(1), 27-33$.

Putra, R., \& Wadisman, C. (2018). Implementasi Data Mining Pemilihan Pelanggan Potensial Menggunakan Algoritma K Means. INTECOMS: Journal of Information Technology $\begin{array}{llll}\text { and } \quad \text { Computer } & \text { Science, }\end{array}$ https://doi.org/https://doi.org/10.31539/intecoms.v1i1.141

Rahayu, N. (2019). Sistem Pakar IQ Dalam Pengelompokan Anak Reterdasi Mental Dengan Algoritma K-Means. INTECOMS: Journal of Information Technology and Computer Science, 2(1), 17-32. https://doi.org/https://doi.org/10.31539/intecoms.v2i1.659

Sulistiyani, M. E., Soedijono, B., \& Syahdan, S. A. (2015). Sistem Penentuan Jurusan Sekolah Menengah Atas Negeri 1 Karangmojo. Seminar Nasional Teknologi Informasi dan Multimedia 2015, 3(1), 247-252.

Yunefri, Y., Pane, E., \& Sutejo, S. (2019). Pengembangan Sistem Pengelompokan Belajar Mahasiswa Pada Matakuliah Struktur Data Dengan Metode K-Means. INTECOMS: Journal of Information Technology and Computer Science, 2(2), 59-66. https://doi.org/https://doi.org/10.31539/intecoms.v2i2.812 